\title{
Total and dissolved soil organic and inorganic carbon and their relationships in typical loess cropland of Fengu Basin
}

\author{
Tongping Lu, Xiujun Wang ${ }^{*}$ (D) and Wenxi Zhang
}

\begin{abstract}
There is evidence of connections between soil organic carbon (SOC) and inorganic carbon (SIC) in dryland of north China. However, fractions of SOC and SIC and the relationship are not well understood in the Loess Plateau that undergoes profound erosion and redeposition. A study was conducted in low-elevation cropland of Loess Plateau across two distinctive basins: Linfen basin (LFB) with lower soil pH $(<8.4)$ and subject to erosion-redeposition, and Yuncheng basin (YCB) with higher soil pH (> 8.6) and under the influence of the Yellow River. Soil samples were collected from 30 sites over $100 \mathrm{~cm}$. We determined SOC, SIC, dissolved organic carbon (DOC) and other properties. Above $100 \mathrm{~cm}$, SOC stock is significantly higher in LFB $\left(10.0 \pm 2.6 \mathrm{~kg} \mathrm{C} \mathrm{m}^{-2}\right)$ than in YCB $\left(6.9 \pm 1.5 \mathrm{~kg} \mathrm{C} \mathrm{m}^{-2}\right)$, but $\mathrm{SIC}$ lower in LFB $\left(14.0 \pm 2.5 \mathrm{~kg} \mathrm{C} \mathrm{m}^{-2}\right)$ than in YCB $\left(17.0 \pm 5.7 \mathrm{~kg} \mathrm{C} \mathrm{m}^{-2}\right)$. We find a significantly negative correlation between SOC and SIC stocks in LFB, but no clear relationship in YCB. DOC:SOC ratio (an indicator for DOC desorption or SOC stability) is significantly higher below $40 \mathrm{~cm}$ in YCB (1.9\%) than LFB (1.2\%), indicating stronger DOC desorption in YCB that has stronger hydrological process due to the influence of the Yellow River. Overall, SOC has a negative correlation with $\mathrm{SIC}$ and soil $\mathrm{pH}$, and DOC:SOC ratio has a significantly positive correlation with soil pH. Our analyses suggest that erosion/re-deposition of topsoil is partly responsible for the negative SIC-SOC relationship in LFB, and high soil pH and stronger hydrological processes are attributable to relatively lower levels of SOC in YCB. This study highlights that soil carbon fractions in the lowland of Loess Plateau are influenced by many drivers, which leads to complex relationships between major soil carbon pools.
\end{abstract}

Keywords: Soil organic carbon, Soil inorganic carbon, Dissolved carbon, Loess cropland, Fengu Basin

\section{Introduction}

The storage ( $1500 \mathrm{Pg})$ of soil organic carbon (SOC) is greater than the sum of carbon stock in the atmosphere $(\sim 750 \mathrm{Pg})$ and terrestrial biosphere $(\sim 560 \mathrm{Pg})$, acting as both sources and sinks and contributing huge share to the regional and/or global carbon budgets (Amundson 2001; Jobbágy and Jackson 2000). The pool of soil inorganic carbon (SIC) is comparable to that of SOC in both the global land (Lal 2004) and China's land (Li et al. 2007). Although there are many studies that demonstrate

\footnotetext{
*Correspondence: xwang@bnu.edu.cn

College of Global Change and Earth System Science, Beijing Normal

University, Beijing 100875, People's Republic of China
}

some kinds of connection between SOC and SIC (Mehra et al. 2019; Monger et al. 2015; Zamanian et al. 2016), the relationship between SOC and SIC has not been well understood.

There are some studies addressing SIC-SOC relationship, which report inconsistent findings. While there is evidence of a positive correlation between SIC and SOC stocks in the cropland of north China (Guo et al. 2016; Shi et al. 2017b; Wang et al. 2015b), studies also report a negative SIC-SOC relationship under various land uses in the North China (Li et al. 2010; Zhao et al. 2016). In particular, Zhao et al. (2016) found that SOC had a negative relationship with SIC under mixed land uses (i.e., forest, 
grass, shrub lands) in the Loess Plateau that undergoes profound erosion.

The differences in SIC-SOC relationship may reflect the differences in the responses to changes in environmental conditions between SOC and SIC. For instance, there is evidence that high soil $\mathrm{pH} /$ salinity often leads to low levels of SOC (partly due to low stability of SOC) (Chen et al. 2017; Demoling et al. 2007), but high levels of SIC probably owing to high levels of $\mathrm{Ca}^{2+} / \mathrm{Mg}^{2+}$ (Oste et al. 2002; Wang et al. 2015a). Recent studies suggest that hydrologic processes may have influences on various fractions of soil carbon (Lu et al. 2020; Zhang et al. 2020), particularly on dissolved organic carbon (DOC) and inorganic carbon (DIC), which could alter the SICSOC relationship. For example, low SOC stability (under high $\mathrm{pH} /$ salinity) often result in more desorption of DOC (Mavi et al. 2012) whereas hydrologic processes may enhance both desorption of DOC and the dissolution of SIC (Shi et al. 2017a; Zhang et al. 2020). On the other hand, there is also evidence that higher levels of $\mathrm{CaCO}_{3}$ or $\mathrm{Ca}^{2+} / \mathrm{Mg}^{2+}$ are beneficial for SOC stabilization (Tavakkoli et al. 2015; Virto et al. 2011) because of enhanced formation of soil aggregates (Rowley et al. 2018).

There have been some studies on soil carbon dynamics in the Loess Plateau, showing large variability in both SOC and SIC, which is influenced by many environmental factors such as climate (e.g., precipitation, temperature), and vegetation types (Han et al. 2018; Liu et al. 2011). The Loess Plateau has undergone severe soil erosions due to the poor structure of loess (Fu et al. 2011). Numerous studies have reported that erosion associated processes, including detachment, transport and deposition of soil materials, have large impacts on SOC distribution (Schiettecatte et al. 2008; Zhu et al. 2014).

There is a distinctive difference in vertical distribution between SOC and SIC in the north China's cropland: i.e., a sharp decrease in SOC but a general increase in SIC with depth (Shi et al. 2017b; Zhang et al. 2015). Erosion and redeposition of topsoil from highlands to lowlands could have influences on the storages of both SOC and SIC, thus altering the SOC-SIC relationship in the Loess Plateau. The Fengu Basin, consisting of Linfen Basin (LFB) and Yuncheng Basin (YCB), is located at the southeast edge of the Loess Plateau, which is subject to erosion-redeposition (in LFB) and under the influence of Yellow River (In YCB). We hypothesize that the relationship between SIC and SOC is more complex in the cropland of Fengu Basin (relative to other regions of north China, e.g., the North China Plain) because of different influences of erosion-redeposition and hydrological processes that have large impacts on soil carbon, particularly on DOC and DIC. The objectives of this work are to study the dynamics of SOC and SIC and their dissolved fractions in the low-elevation cropland of the Loess Plateau, to assess the relationship between these soil carbon fractions, and to explore the underlying mechanism responsible for the variability of SOC and SIC in a semiarid region.

\section{Materials and methods}

\section{Characteristics of the study area}

Our study area $\left(110^{\circ} 24^{\prime} 12^{\prime \prime}-111^{\circ} 42^{\prime} 29^{\prime \prime}\right.$ E, $34^{\circ} 54^{\prime} 43^{\prime \prime}$ $-36^{\circ} 15^{\prime} 52^{\prime \prime} \mathrm{N}, \sim 4000 \mathrm{~km}^{2}$ ) is located at the southwest of Shanxi Province on the Loess Plateau in China (Fig. 1), which spans almost the entire Fengu Basin's cropland. The area is dominated by semiarid continental monsoon climate with noticeable seasonal changes: a severely dry spring, hot and rainy summer, and a cold and dry winter. Main soil type is identified as Calcareous cinnamon (Huang et al. 2007; Shi et al. 2006). The region has an agricultural history of thousands of years. At present, a double-cropping system, i.e., winter wheat and summer maize rotation is being practiced, with similar fertilization and tillage management. Irrigation is often applied using waters from the rivers.

Despite the similarity in climate and agricultural practice, there are some differences in other aspects between the LFB and YCB. LFB is a canyon basin with an elevation of 389-554 $\mathrm{m}$ and Fenhe river flowing from the north to the south, which is surrounded by mountains $(>1000 \mathrm{~m}$ a.s.l.). The parent material in the region is redeposited loess. Annual mean temperature is $8.9-12.9{ }^{\circ} \mathrm{C}$. Annual mean precipitation ranges from 420 at a lower altitude to $550 \mathrm{~mm}$ at a higher altitude, with $70 \%$ during June-September. Annual average evaporation is $\sim 1660 \mathrm{~mm}$.

The parent material in the YCB is the alluvial loess. The elevation varies from 380 to $820 \mathrm{~m}$. Annual mean temperature is $\sim 13{ }^{\circ} \mathrm{C}$, and annual mean evaporation is $\sim 1800 \mathrm{~mm}$. Annual precipitation has a range of $\sim 500$ $750 \mathrm{~mm}$, showing an increasing trend with an increase in elevation, and $69 \%$ during the period of June-September. The majority of YCB is influenced by the Yellow River, and the northern part is also influenced by Fenhe river.

\section{Soil sampling and analyses}

Soil samples were collected in late-August 2017 from 30 sites (Fig. 1) using a soil auger to a depth of $100 \mathrm{~cm}$, at $20-\mathrm{cm}$ intervals. At each site, four soil cores were randomly taken, and soils for each layer were mixed. Soil bulk density was determined for the $0-20,20-40$ and $40-60 \mathrm{~cm}$ at several representative sites. Soils were air-dried, crushed, mixed thoroughly and passed 2-mm screen. A portion of soil samples was crushed to $<0.25 \mathrm{~mm}$, which were used for the measurements of total carbon (TC), SOC and total nitrogen (TN). We prepared soil-water mixtures (1:5) using 2-mm soils for 


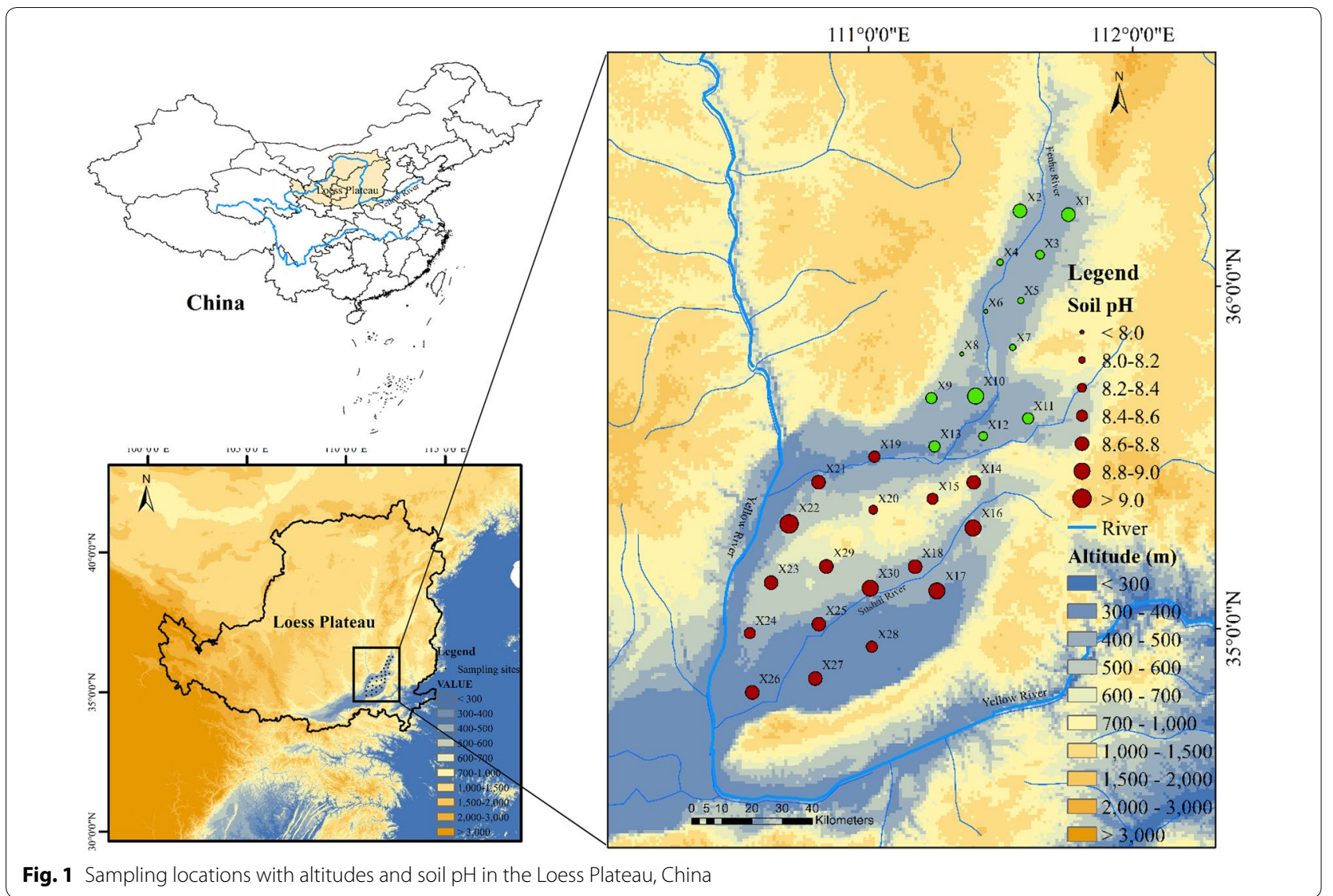

measurements of soil $\mathrm{pH}$, electrical conductivity (EC), and water-extractable $\mathrm{Ca}^{2+}$ and $\mathrm{Mg}^{2+}$ (using an Atomic Absorption Spectrophotometer). Contents of TC and TN were measured using a CNHS-O analyzer (Model EuroEA3000). SOC content was determined by $\mathrm{K}_{2} \mathrm{Cr}_{2} \mathrm{O}_{7}$ oxidation titration (Walkley and Black 1934). Content of SIC was obtained by subtracting SOC from TC.

For the measurements of DOC and DIC, $6 \mathrm{~g}$ 2-mm soil was treated with $24 \mathrm{ml} 0.05 \mathrm{M} \mathrm{K}_{2} \mathrm{SO}_{4}$ solution for $4 \mathrm{~h}$ at $25^{\circ} \mathrm{C}$, the mixture was shaken for one hour, and followed by centrifugation. The supernatant was filtered through a $0.45-\mu \mathrm{m}$ membrane, then TC and DIC were determined by a TOC analyzer (TOC-VCPH, Shimadzu). Concentration of DOC was calculated by the difference between TC and IC.

\section{Data calculation and statistical analyses}

Stocks of SOC, SIC and DOC were calculated using the following equations:

$$
X_{\text {stock }}=\sum_{i=1}^{n} X_{i} \times B_{i} \times \frac{D_{i}}{100}
$$

where $X_{i}$ is carbon content for layer $i, D_{i}$ soil layer thickness $(\mathrm{cm}), B_{\mathrm{i}}$ bulk density $\left(\mathrm{g} \mathrm{cm}^{-3}\right)$, and $n$ the number of soil layers.

The normality test of our data on organic and inorganic carbon shows a normal distribution. Two-way analyses of variance followed by the least significant differences (LSD) were performed to evaluate the differences of various soil indices between basins and layers. Linear regression analyses were employed to analyze the SOC-SIC relationship, and the relationship between DOC:SOC ratio and other soil properties. Statistical analysis was executed using SPSS 19.0.

\section{Results}

Basic soil properties and spatial variations of water-soluble $\mathrm{Ca}+\mathrm{Mg}$ density

As presented in Fig. 1, soil $\mathrm{pH}$ had a small range in both LFB (7.9 8.9) and YCB (8.4 9.1); mean soil pH was significantly lower in the former $(<8.4)$ than in the latter (>8.6) (Table 1). But EC value was observably high in the LFB $(0.49-0.72 \mathrm{mS} / \mathrm{cm})$ than in the YCB $(0.19-0.29 \mathrm{mS} /$ $\mathrm{cm}$ ), with higher values in the subsoil. Soil C:N ratio was similar between LFB (9.2-13.4) and YCB (10.2-12.4) 
Table 1 Basic soil properties in the Linfen basin (LFB) and Yuncheng basin (YCB)

\begin{tabular}{|c|c|c|c|c|c|c|c|c|}
\hline \multirow[t]{2}{*}{ Layer $(\mathrm{cm})$} & \multicolumn{2}{|l|}{ BD } & \multicolumn{2}{|l|}{$\mathrm{pH}$} & \multicolumn{2}{|c|}{$\mathrm{EC}(\mathrm{mS} / \mathrm{cm})$} & \multicolumn{2}{|l|}{ C:N } \\
\hline & LFB & YCB & LFB & YCB & LFB & YCB & LFB & YCB \\
\hline $0-20$ & 1.19Ab & $1.23 \mathrm{Ab}$ & $8.20 \mathrm{Ba}$ & $8.64 \mathrm{Aa}$ & $0.48 \mathrm{Ab}$ & $0.19 \mathrm{Ba}$ & 13.4 Aa & $12.3 \mathrm{Aa}$ \\
\hline $20-40$ & 1.35Aab & $1.49 \mathrm{Aa}$ & $8.38 \mathrm{Ba}$ & $8.70 \mathrm{Aa}$ & $0.51 \mathrm{Ab}$ & $0.22 \mathrm{Ba}$ & $11.2 \mathrm{Abc}$ & $12.4 \mathrm{Aa}$ \\
\hline $40-60$ & $1.42 \mathrm{Aa}$ & $1.44 \mathrm{Aa}$ & $8.38 \mathrm{Ba}$ & $8.72 \mathrm{Aa}$ & 0.59 Aab & $0.25 \mathrm{Ba}$ & $10.2 \mathrm{Ac}$ & 10.2 Abc \\
\hline $60-80$ & $1.43 \mathrm{Aa}$ & $1.43 \mathrm{Aa}$ & $8.37 \mathrm{Ba}$ & $8.73 \mathrm{Aa}$ & $0.69 \mathrm{Aa}$ & $0.27 \mathrm{Ba}$ & $9.2 \mathrm{AC}$ & $10.3 \mathrm{Abc}$ \\
\hline 80-100 & $1.44 \mathrm{Aa}$ & $1.45 \mathrm{Aa}$ & $8.38 \mathrm{Ba}$ & $8.78 \mathrm{Aa}$ & $0.72 \mathrm{Aa}$ & $0.29 \mathrm{Ba}$ & $7.3 \mathrm{BC}$ & $9.3 \mathrm{AC}$ \\
\hline
\end{tabular}

Values followed by the same letter (capital letter between two basins and lowercase letter between layers) are not significantly different at $P<0.05$ based on LSD test.

above $80 \mathrm{~cm}$, but significantly lower in LFB (7.3) than in YCB (9.3) over $80-100 \mathrm{~cm}$.

Figure 2 showed that water-soluble $\mathrm{Ca}+\mathrm{Mg}$ (the sum of water-soluble $\mathrm{Ca}^{2+}$ and $\mathrm{Mg}^{2+}$ ) was generally lower in topsoil (i.e., 98 to $341 \mathrm{~g} \mathrm{~m}^{-3}$ ) than in subsoils (i.e., $133-450 \mathrm{~g} \mathrm{~m}^{-3}$ over $20-40 \mathrm{~cm}$, and 134-465 $\mathrm{g} \mathrm{m}^{-3}$ over $40-100 \mathrm{~cm})$. Overall, water-soluble $\mathrm{Ca}+\mathrm{Mg}$ was low at sites in the north of LFB, and at the sites close to the Yellow River in the YCB above $40 \mathrm{~cm}$. Interestingly, water-soluble $\mathrm{Ca}+\mathrm{Mg}$ showed similar spatial pattern and magnitudes over $40-100 \mathrm{~cm}$ to those over $20-40 \mathrm{~cm}$ in the YCB, but overall higher levels in the LFB. There were no significant differences in water-soluble $\mathrm{Ca}+\mathrm{Mg}$ between two basins or over depth (Table 1).

\section{Spatial variations of SOC, DOC density and DOC:SOC ratio}

Figure 3 shows SOC had a larger range in topsoil (5.9$\left.23.0 \mathrm{~kg} \mathrm{C} \mathrm{m}^{-3}\right)$ than in subsoils $\left(4.3-16.7 \mathrm{~kg} \mathrm{C} \mathrm{m}^{-3}\right.$ over $20-40 \mathrm{~cm}$, and $3.1-12.1 \mathrm{~kg} \mathrm{C} \mathrm{m}^{-3}$ over $40-100 \mathrm{~cm}$ ). Overall, SOC density was greater in LFB than in YCB, especially in subsoils, although there were a couple of sites (along the Fenhe river and Yellow River) showing high levels of SOC over $20-40 \mathrm{~cm}$ in YCB. It appeared that SOC density was lower at high-altitude sites, in particular over $0-20 \mathrm{~cm}$.

DOC varied from 64 to $147 \mathrm{~g} \mathrm{C} \mathrm{m}^{-3}$ in LFB, and 45 to $118 \mathrm{~g} \mathrm{C} \mathrm{m}^{-3}$ in YCB over $0-20 \mathrm{~cm}$ (Fig. 3b), showing a similar spatial distribution with SOC (Fig. 3a). However, the spatial pattern of DOC was somehow different from that of SOC in subsoils. Overall, DOC level in subsoil was higher in the YCB than in the LFB. For example, DOC over $40-100 \mathrm{~cm}$ varied from 46 to $106 \mathrm{~g} \mathrm{C} \mathrm{m}^{-3}$ in LFB, but $48-144 \mathrm{~g} \mathrm{C} \mathrm{m}^{-3}$ in the YCB.

Ratio of DOC:SOC ranged from $0.37 \%$ to $0.98 \%$ over $0-20 \mathrm{~cm}, 0.49 \%$ to $1.87 \%$ over $20-40 \mathrm{~cm}$, and $0.71 \%$ to $2.52 \%$ over $40-100 \mathrm{~cm}$ (Fig. 4). Despite a large spatial variability, DOC:SOC ratio showed a general higher values in YCB than in LFB in particular below $40 \mathrm{~cm}$. As shown in Table 2, mean DOC:SOC ratio was slightly higher in the YCB $(0.76-1.09 \%)$ than in the LFB $(0.61-0.95 \%)$ above $40 \mathrm{~cm}$, significantly higher in the YCB (1.24\%) than in the LFB (1.88\%) below $40 \mathrm{~cm}$. It appeared that lower ratio of DOC:SOC was found at sites in high-altitude and far away from the Yellow River.

\section{Spatial variations of SIC and DIC density}

SIC also showed large spatial variation, with a range from 1.5 to $37.8 \mathrm{~kg} \mathrm{C} \mathrm{m}^{-3}$ above $20 \mathrm{~cm}, 7.7$ to $25.5 \mathrm{~kg} \mathrm{C} \mathrm{m}^{-3}$ over $20-40 \mathrm{~cm}$, and 5.3 to $28.2 \mathrm{~kg} \mathrm{C} \mathrm{m}^{-3}$ over $40-100 \mathrm{~cm}$ (Fig. 5a, c, e). Overall, lower levels of SIC were found in the north LFB; however, the lowest SIC $\left(<5 \mathrm{~kg} \mathrm{C} \mathrm{m}^{-3}\right)$ was at high-altitude sites in the YCB over $40-100 \mathrm{~cm}$. Nevertheless, the highest levels of SIC $\left(>37 \mathrm{~kg} \mathrm{C} \mathrm{m}^{-3}\right)$ were found in the YCB for all soil layers. It appeared that the spatial variability of SIC was larger over $20-40$ and $40-100 \mathrm{~cm}$ than over $0-20 \mathrm{~cm}$.

The spatial pattern of DIC was markedly different between the three layers although the range was similar, i.e., from 34 to $85 \mathrm{~g} \mathrm{C} \mathrm{m}^{-3}$ over $0-20 \mathrm{~cm}, 37$ to $96 \mathrm{~g} \mathrm{C} \mathrm{m}^{-3}$ over $20-40 \mathrm{~cm}$, and 38 to $98 \mathrm{~g} \mathrm{C} \mathrm{m}^{-3}$ over 40-100 cm (Fig. 5b, d, f). Overall, the spatial distribution of DIC showed no similarity to that of SIC (Fig. 5). For the 0-20 cm layer, high DIC $\left(>50 \mathrm{~g} \mathrm{C} \mathrm{m}^{-3}\right)$ was found at sites in the north and south part of LFB and the southwest of YCB. However, DIC below $40 \mathrm{~cm}$ displayed high values $\left(>60 \mathrm{~g} \mathrm{C} \mathrm{m}^{-3}\right)$ at sites in the east of YCB. In general, low values of DIC were found at sites near the Yellow River below $20 \mathrm{~cm}$ (Fig. 5d, f).

\section{The relationship between carbon fractions}

Figure 6 shows a significant negative correlation between SIC and SOC stocks using the entire dataset (30 sites) over both $0-20 \mathrm{~cm}(P<0.05)$ and $0-100 \mathrm{~cm}(P<0.01)$. On a regional scale, there was a significantly negative correlation between SIC and SOC stocks in LFB over the $0-20 \mathrm{~cm} \quad(P<0.01)$ and $0-100 \mathrm{~cm} \quad(P<0.05)$, but weak or no significant correlation in YCB. Our analysis also showed a strong positive relationship $(P<0.01)$ between DOC and SOC over $0-20 \mathrm{~cm}$ in both LFB and YCB. However, for the $20-100 \mathrm{~cm}$ layer, DOC had a 

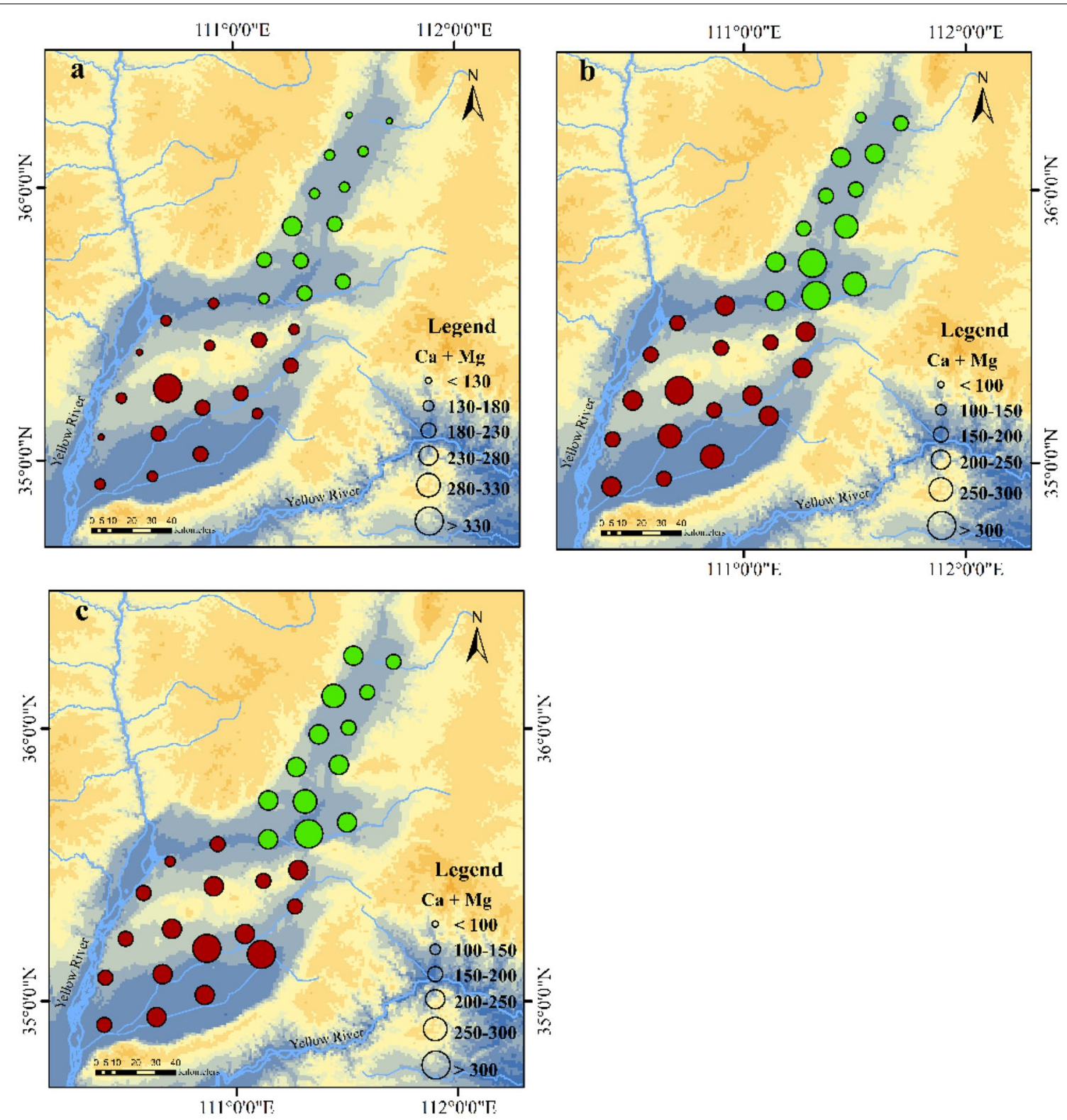

Fig. 2 Density $\left(\mathrm{g} \mathrm{m}^{-3}\right.$ ) of water soluble Ca + Mg over (a) 0-20 cm, (b) 20-40 cm, and (c) 40-100 cm in the YCB (red) and LFB (green). The figure was generated using ArcMap 10.5 (https://www.esri.com/)

significantly positive correlation with SOC only in the YCB (Fig. 7).

\section{Discussion}

\section{Variations of SOC and SIC in loess cropland}

On average, SOC content is significantly higher in the whole soil profile in the LFB $\left(4.35-15.1 \mathrm{~g} \mathrm{~kg}^{-1}\right)$ relative to YCB (3.14-10.3 $\mathrm{g} \mathrm{kg}^{-1}$ ) (Table 2). Previous studies have demonstrated that erosion can transport topsoil from highlands to lowlands, which leads to depositions of SOM/SOC in valleys and basins with lower elevation
(Liu et al. 2011; Zheng et al. 2005; Zhong and Xu 2009). The LFB, as a valley, may have accumulated a thick layer of redeposited topsoil from surrounding highlands that contain high levels of SOC (Liu et al. 2011).

SOC content of the YCB (from $10.3 \mathrm{~g} \mathrm{~kg}^{-1}$ over $0-20 \mathrm{~cm}$ to $3.1 \mathrm{~g} \mathrm{~kg}^{-1}$ over $80-100 \mathrm{~cm}$ ) is similar to those in loess cropland, e.g., from 9.7 to $2.7 \mathrm{~g} \mathrm{~kg}^{-1}$ in the Hebei Plain (Lu et al. 2020), and from 11.0 to $3 \mathrm{~g} \mathrm{~kg}^{-1}$ in the west part of Loess Plateau (Liu et al. 2018; Zhang et al. 2015). The relative low levels of SOC in those loess croplands may be largely related to the texture of loess that has less 

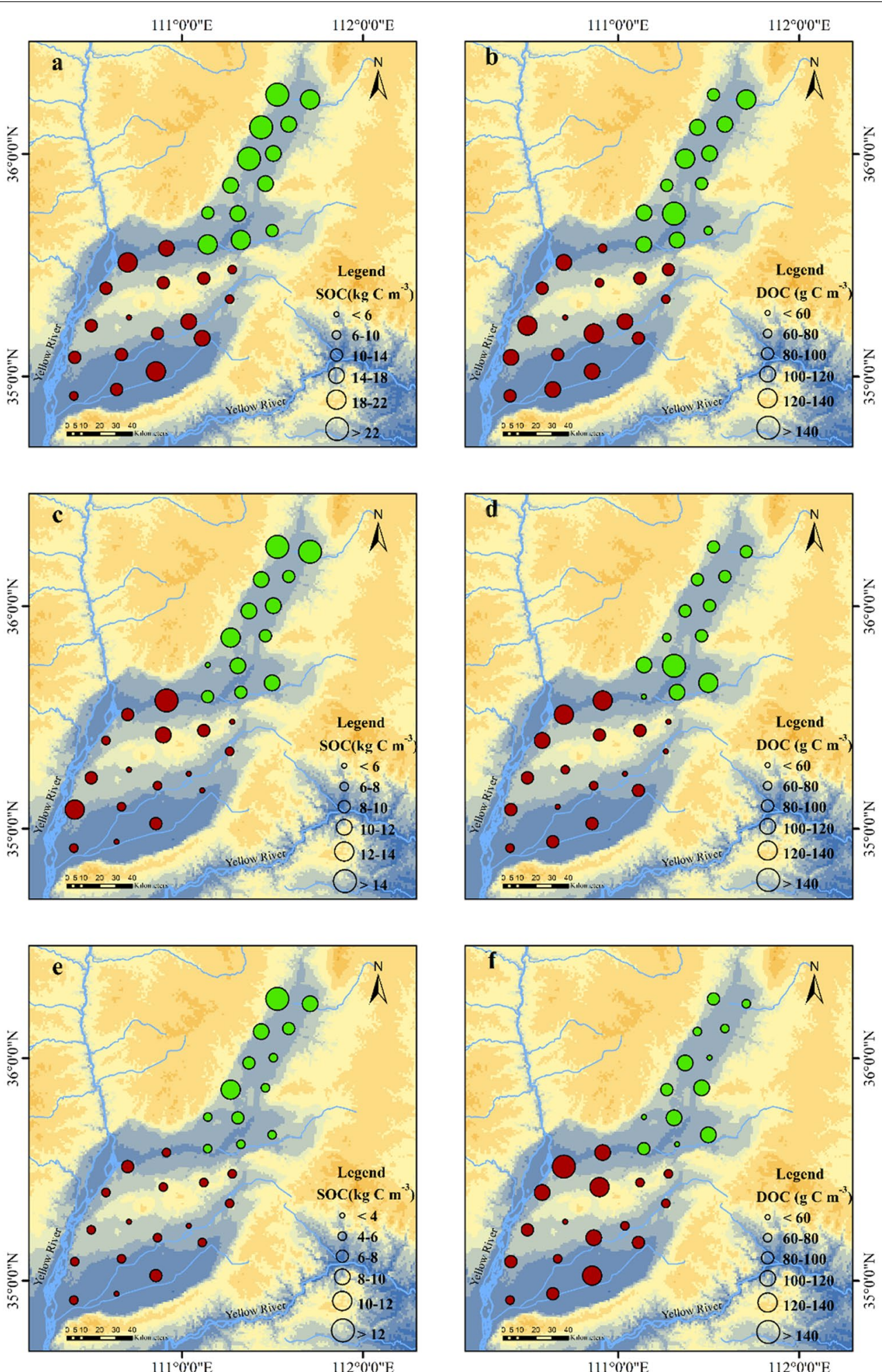

Fig. 3 Density of soil organic carbon (SOC) (left panel) and dissolved organic carbon (DOC) (right panel) over (a, b) $0-20 \mathrm{~cm}$, (c, d) $20-40 \mathrm{~cm}$, and (e, f) 40-100 cm in the YCB (red) and LFB (green). The figure was generated using ArcMap 10.5 (https://www.esri.com/) 

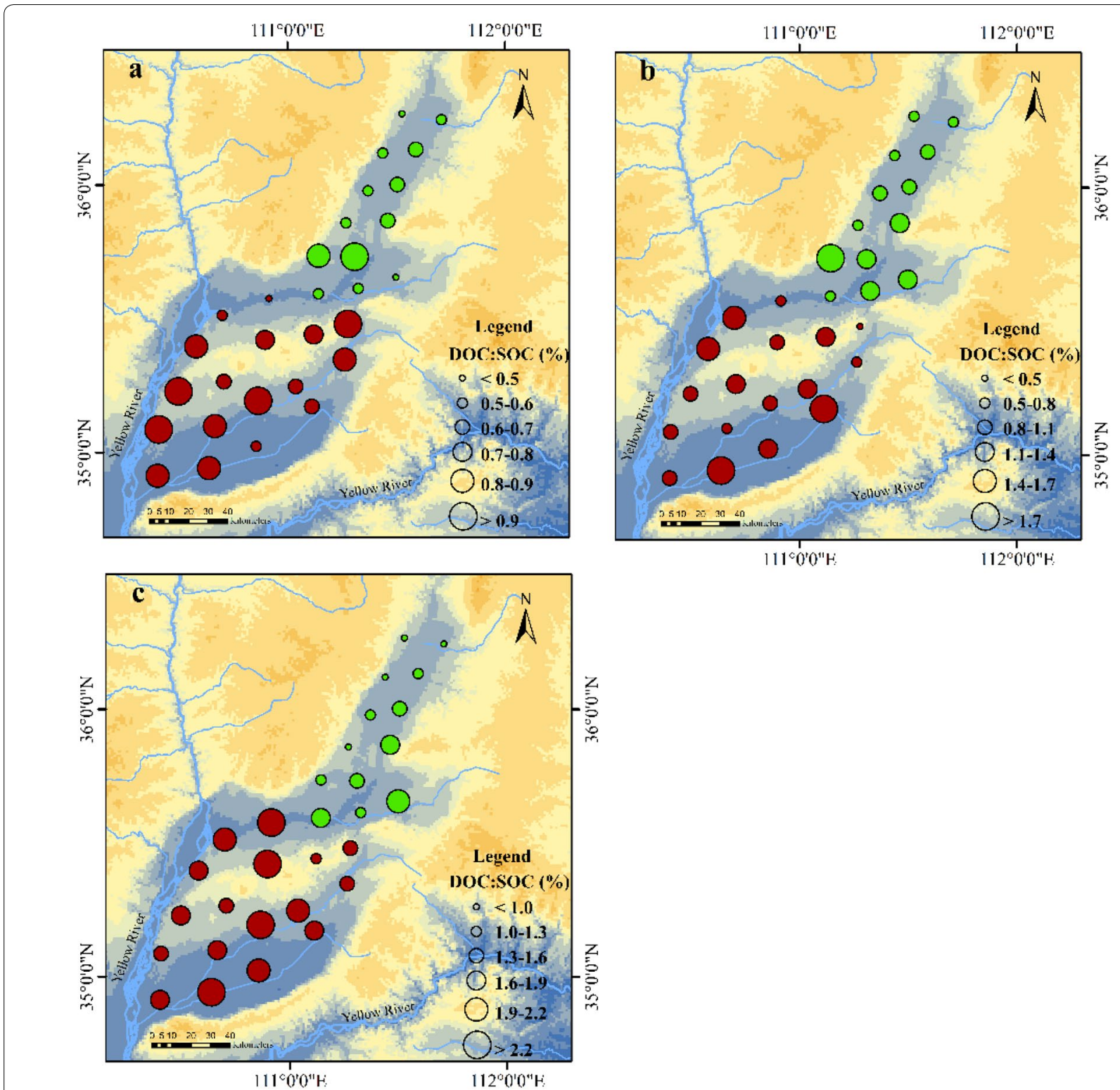

Fig. 4 Ratio of dissolved organic carbon and soil organic carbon (DOC:SOC, \%) over (a) 0-20 cm, (b) 20-40 cm, and (c) 40-100 cm in the YCB (red) and LFB (green). The figure was generated using ArcMap 10.5 (https://www.esri.com/)

Table 2 Main soil carbon forms and their ratios in the Linfen basin (LFB) and Yuncheng basin (YCB)

\begin{tabular}{|c|c|c|c|c|c|c|c|c|c|c|c|c|}
\hline \multirow[t]{2}{*}{ Depth (cm) } & \multicolumn{2}{|c|}{ SOC $(g / k g)$} & \multicolumn{2}{|c|}{ SIC (g/kg) } & \multicolumn{2}{|c|}{$\mathrm{DOC}(\mathrm{mg} / \mathrm{kg})$} & \multicolumn{2}{|c|}{ DIC (mg/kg) } & \multicolumn{2}{|c|}{ DOC:SOC (\%) } & \multicolumn{2}{|c|}{ DIC:SIC (\%) } \\
\hline & LFB & YCB & LFB & YCB & LFB & YCB & LFB & YCB & LFB & YCB & LFB & YCB \\
\hline $0-20$ & 15.1 $\mathrm{Aa}$ & $10.3 \mathrm{Ba}$ & $9.17 \mathrm{Bb}$ & 12.1 Aab & $90.1 \mathrm{Aa}$ & 75.2 Ba & $43.1 \mathrm{Aa}$ & 41.3 Aa & $0.61 \mathrm{AC}$ & $0.76 \mathrm{AC}$ & $0.91 \mathrm{Aa}$ & $0.39 \mathrm{Ba}$ \\
\hline $20-40$ & $8.02 \mathrm{Ab}$ & $5.75 \mathrm{Bb}$ & $9.69 \mathrm{Bb}$ & $11.4 \mathrm{Ab}$ & $71.1 \mathrm{Ab}$ & $59.3 \mathrm{Bb}$ & $37.4 \mathrm{Aa}$ & 42.2 $\mathrm{Aa}$ & $0.95 \mathrm{Ab}$ & $1.09 \mathrm{Ab}$ & $0.43 \mathrm{Ab}$ & $0.39 \mathrm{Aa}$ \\
\hline $40-60$ & $5.73 \mathrm{Ac}$ & $3.91 \mathrm{BC}$ & $9.29 \mathrm{Bb}$ & 12.2 Aab & & & & & & & & \\
\hline $60-80$ & $4.95 \mathrm{Ac}$ & $3.38 \mathrm{BC}$ & $10.6 \mathrm{Bb}$ & 13.4 Aa & 57.3 Ac & $64.9 \mathrm{Ab}$ & $41.5 \mathrm{Aa}$ & 41.8 $\mathrm{Aa}$ & $1.24 \mathrm{Ba}$ & $1.88 \mathrm{Aa}$ & $0.39 \mathrm{Ab}$ & $0.39 \mathrm{Aa}$ \\
\hline $80-100$ & $4.35 \mathrm{Ac}$ & $3.14 \mathrm{BC}$ & $12.5 \mathrm{Aa}$ & $12.8 \mathrm{Aa}$ & & & & & & & & \\
\hline
\end{tabular}



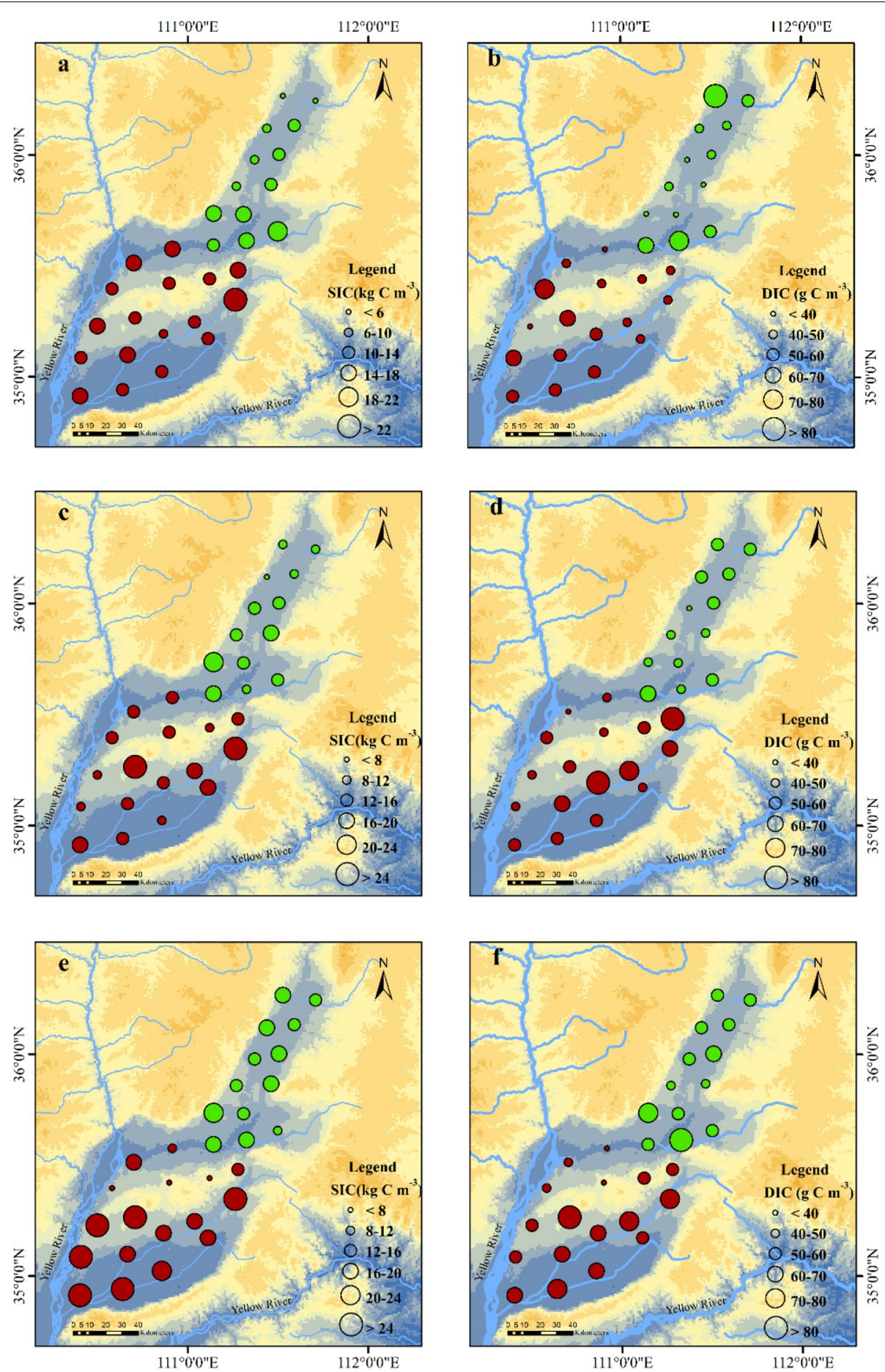

Fig. 5 Density of soil inorganic carbon (SIC) (left panel) and dissolved inorganic carbon (DIC) (right panel) over (a, b) $0-20 \mathrm{~cm}$, (c, d) $20-40 \mathrm{~cm}$, and $($ e, f) 40-100 cm in the YCB (red) and LFB (green). The figure was generated using ArcMap 10.5 (https://www.esri.com/)

clay thus less protection for SOM (Li et al. 2019, 2017). In addition, hydrological processes associated with the Yellow River may lead to enhanced desorption/removal of DOC from soil profile, which is partly responsible for the relatively lower SOC in the loess croplands (Shi et al. 2017a; Zhang et al. 2020).

Our study showed that SIC was significantly lower in LFB (9.2-10.6 $\left.\mathrm{g} \mathrm{kg}^{-1}\right)$ than in YCB (11.4-13.4 $\left.\mathrm{g} \mathrm{kg}^{-1}\right)$ 

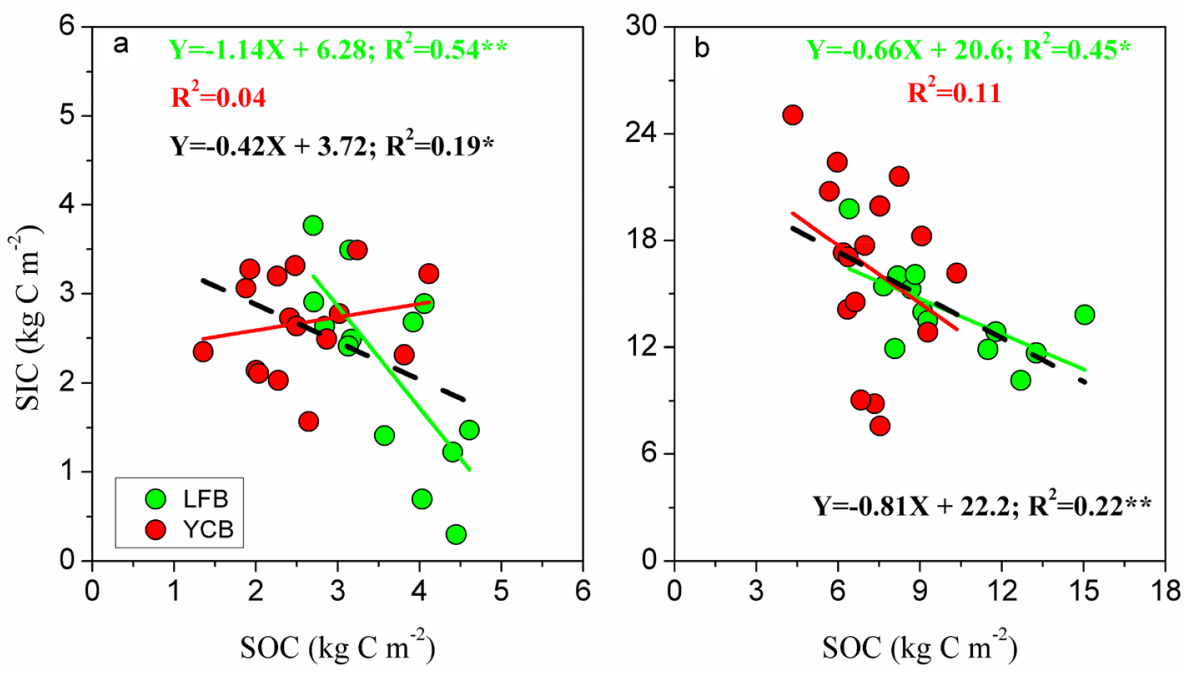

Fig. 6 Correlation between SIC and SOC stocks in LFB, YCB and combined data (black dash lines) over (a) $0-20 \mathrm{~cm}$, (b) $0-100 \mathrm{~cm}$. One asterisk indicates significance at $P<0.05$, and two asterisks at $P<0.01$
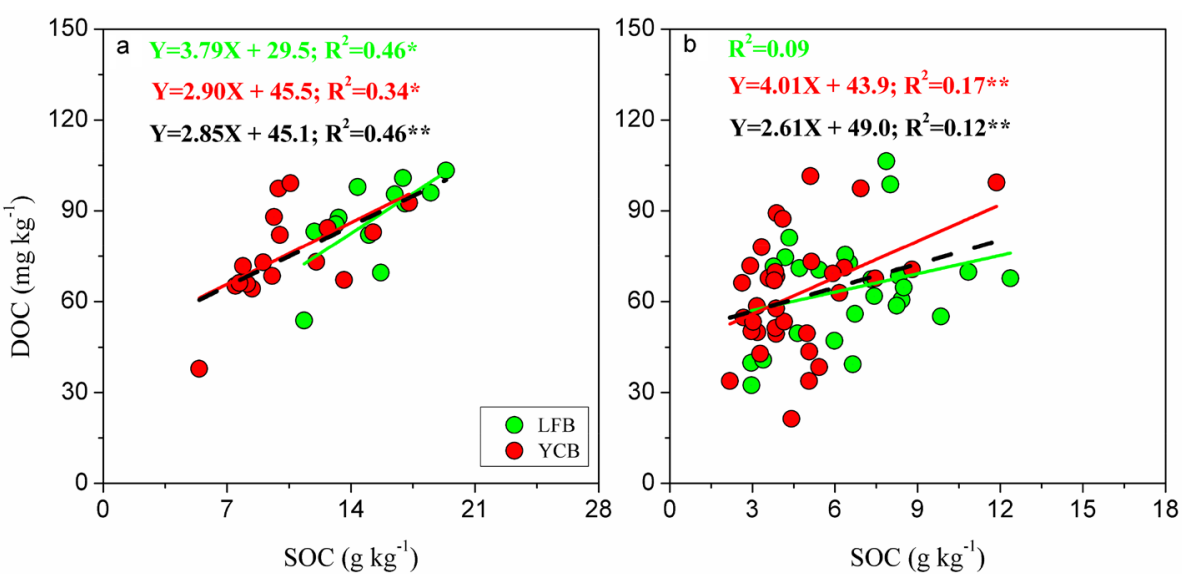

Fig. 7 Correlation between DOC and SOC content in the LFB, YCB and combined data (black dash lines) over (a) $0-20 \mathrm{~cm}$ and (b) $20-100 \mathrm{~cm}$. One asterisk indicates significance at $P<0.05$, and two asterisks at $P<0.01$

above $80 \mathrm{~cm}$, which corresponded with significantly higher DIC:SIC ratio in the LFB (0.91\%) than in the YCB $(0.39 \%)$ in the topsoil (Table 2$)$. There were some studies on SIC dynamics in the croplands of north China that have the same or similar parent materials, such as in the Loess Plateau (Zhang et al. 2015) and the North China Plain (Guo et al. 2016; Shi et al. 2017b). Clearly, SIC content in the LFB (with redeposited topsoil) is much lower than that in the western highland $\left(>15 \mathrm{~g} \mathrm{~kg}^{-1}\right)$ of Loess Plateau (Zhang et al. 2015) that has much drier climate and higher soil pH (Table 3). Interestingly, SIC levels in the YCB are close to those (10.5-12.7 $\left.\mathrm{g} \mathrm{kg}^{-1}\right)$ in the upper YRD (Guo et al. 2016), but modest higher than those (7.1-11.4 $\mathrm{g} \mathrm{kg}^{-1}$ ) in the North China Plain (Shi et al. 2017b) though all soils had same parent materials and similar climatic conditions (Table 3). Both the YCB and upper YRD are close to the Yellow River, thus experience strong influences of hydrological processes that could supply extra $\mathrm{Ca}$ and $\mathrm{Mg}$ ions over the past, which is beneficial for SIC formation (Guo et al. 2016).

\section{The relationship between SIC and SOC in loess}

Our analysis shows no clear relationship between SIC and SOC stocks in YCB, but a significant negative correlation between SIC and SOC stocks in the LFB. The overall negative correlation of SIC and SOC in this study area 
Table 3 Comparisons of climate conditions and soil variables (mean and standard deviation) in different study areas under the same/similar parent material

\begin{tabular}{|c|c|c|c|c|c|c|c|c|c|}
\hline Study area & $\begin{array}{l}\text { Elevation } \\
\text { (m) }\end{array}$ & $\begin{array}{l}\text { parent } \\
\text { material }\end{array}$ & $\begin{array}{l}\text { Temperature } \\
\left({ }^{\circ} \mathrm{C}\right)\end{array}$ & $\begin{array}{l}\text { precipitation } \\
(\mathrm{mm})\end{array}$ & $\begin{array}{l}\text { Evaporation } \\
(\mathrm{mm})\end{array}$ & $\mathrm{pH}$ & $\mathrm{EC}(\mathrm{mS} / \mathrm{cm})$ & $\begin{array}{l}\mathrm{SOC}(\mathrm{kg} \\
\left(\mathrm{m}^{-2}\right)\end{array}$ & $\operatorname{SIC}\left(\mathrm{kg} \mathrm{C} \mathrm{m}^{-2}\right)$ \\
\hline $\mathrm{LZ}^{\mathrm{a}}$ & $1700-2000$ & Loess & 9.6 & $250-350$ & 1500 & $8.94(0.22)$ & $0.19(0.06)$ & $5.73(1.68)$ & $22.3(3.13)$ \\
\hline$N C P^{b}$ & $6-112$ & Alluvial loess & 12.5 & $500-600$ & 1900 & $8.64(0.21)$ & $0.22(0.09)$ & $7.51(1.47)$ & $16.5(2.04)$ \\
\hline $\mathrm{YRD}^{c}$ & $11-35$ & Alluvial loess & 13.4 & $530-640$ & 2100 & $8.20(0.08)$ & $0.34(0.16)$ & $5.73(1.31)$ & $16.89(2.52)$ \\
\hline$L_{F B}{ }^{d}$ & $389-554$ & $\begin{array}{l}\text { Redeposited } \\
\text { loess }\end{array}$ & $8.9-12.9$ & $420-550$ & 1659 & $8.34(0.19)$ & $0.61(0.28)$ & $10.0(2.56)$ & $14.0(2.51)$ \\
\hline$Y C B^{d}$ & $380-820$ & Alluvial loess & 13.3 & $500-750$ & 1810 & $8.71(0.21)$ & $0.24(0.14)$ & $6.96(1.50)$ & $16.9(5.71)$ \\
\hline
\end{tabular}

The numbers in brackets represent the standard deviation

LZ-Lanzhou, NCP-Northern China Plan, YRD-upper Yellow River Delta, LFB-Linfeng Basin, YCB-Yuncheng Basin

a (Zhang et al. 2015)

b (Shi et al. 2017b)

c (Guo et al. 2016)

d This study

disagrees with our previous findings of a positive correlation in the loess cropland of North China Plain (Guo et al. 2016; Shi et al. 2017b), and under various land uses in northwest China (Gao et al. 2018; Wang et al. 2015b). There is also evidence of a negative SIC-SOC relationship in the cropland of Hebei Plain (Li et al. 2010) and under various land use types in the Loess Plateau, north China (Zhao et al. 2016).

We found a negative SIC-SOC relationship in the LFB, which was consistent with a report for another part of the Loess Plateau (Zhao et al. 2016). Soil erosion and redeposition/redistribution are profound in the Loess Plateau (Zheng et al. 2005), which would move topsoil from highlands to lowlands, leading to enhanced SOC storage (but with lower SIC stock) in upper $100 \mathrm{~cm}$ (Table 3). In addition, elevated SOC level in the soil profile of LFB could also result in more $\mathrm{CO}_{2}$ production thus lower $\mathrm{pH}$ (Table 1), which causes dissolution of soil carbonate (Chang et al. 2012; Raheb et al. 2017).

The non-significantly SIC-SOC relationship in YCB may reflect the complex influences of multi drivers. There is evidence that precipitation has large impacts on both SOC and SIC in arid/semi-arid lands (Li et al. 2007; Raheb et al. 2017; Wu et al. 2009), particularly in the Loess Plateau (Han et al. 2018). The YCB has a large spatial variation in both precipitation $(500-750 \mathrm{~mm})$ and elevation (380-820 $\mathrm{m}$ a.s.l.), which could have large impacts on the distributions of SOC and SIC, leading to alterations of the SIC-SOC relationship. Our analyses indicate that there is an increasing trend (from 1.0 to 5.8) in SIC:SOC ratio with increasing elevation in the YCB. In addition, the distance from the Yellow River is probably another factor that can alter the SIC-SOC relationship through the influences of hydrological processes on either SIC (Shi et al. 2017b) or SOC (Shi et al. 2017a). We further discuss the potential influence of hydrological processes on SOC below.

\section{Regulating factors for $\mathrm{SOC}$}

The variability of SOC is large under the same cropping system in the loess of north China (Fig. 3 and Shi et al. 2017b), implying that "outputs" of SOC/SOM (e.g., decomposition of SOM), rather than "inputs", primarily regulate the dynamics of SOC, which is influenced by environmental conditions (Liu et al. 2011; Shirale et al. 2019). Given that subsoils are mainly subject to decomposition, we evaluate the relationships between soil carbon indices and other variables over $40-100 \mathrm{~cm}$. Our analyses show that SOC has a positive correlation with $\mathrm{EC}$ and a negative correlation with soil pH (Fig. 6). There is evidence that high EC in saline soils can cause flocculation of clay particles into aggregates, which restricts substrate availability for microbial thus retards decomposition of SOM (Wong et al. 2010). Additionally, soils with high $\mathrm{pH}$ often have poor physical-chemical conditions that are harmful to crop growth and root system development, resulting in less organic carbon inputs into the soil (Kemmitt et al. 2006; Wong et al. 2010).

In addition to the decomposition process, desorption could also lead to lower SOC (Kalbitz et al. 2000; Mavi et al. 2012). Our analyses show that DOC:SOC ratio (representing desorption potential) is positively correlated with $\mathrm{pH}$, and negatively correlated with $\mathrm{EC}$ in subsoils (Fig. 8). There are studies demonstrating that high soil $\mathrm{pH}$ can destroy soil aggregates, thus reduce the protection of SOM against degradation (Kalbitz et al. 2000; Tavakkoli et al. 2015) whereas high EC may be beneficial for 

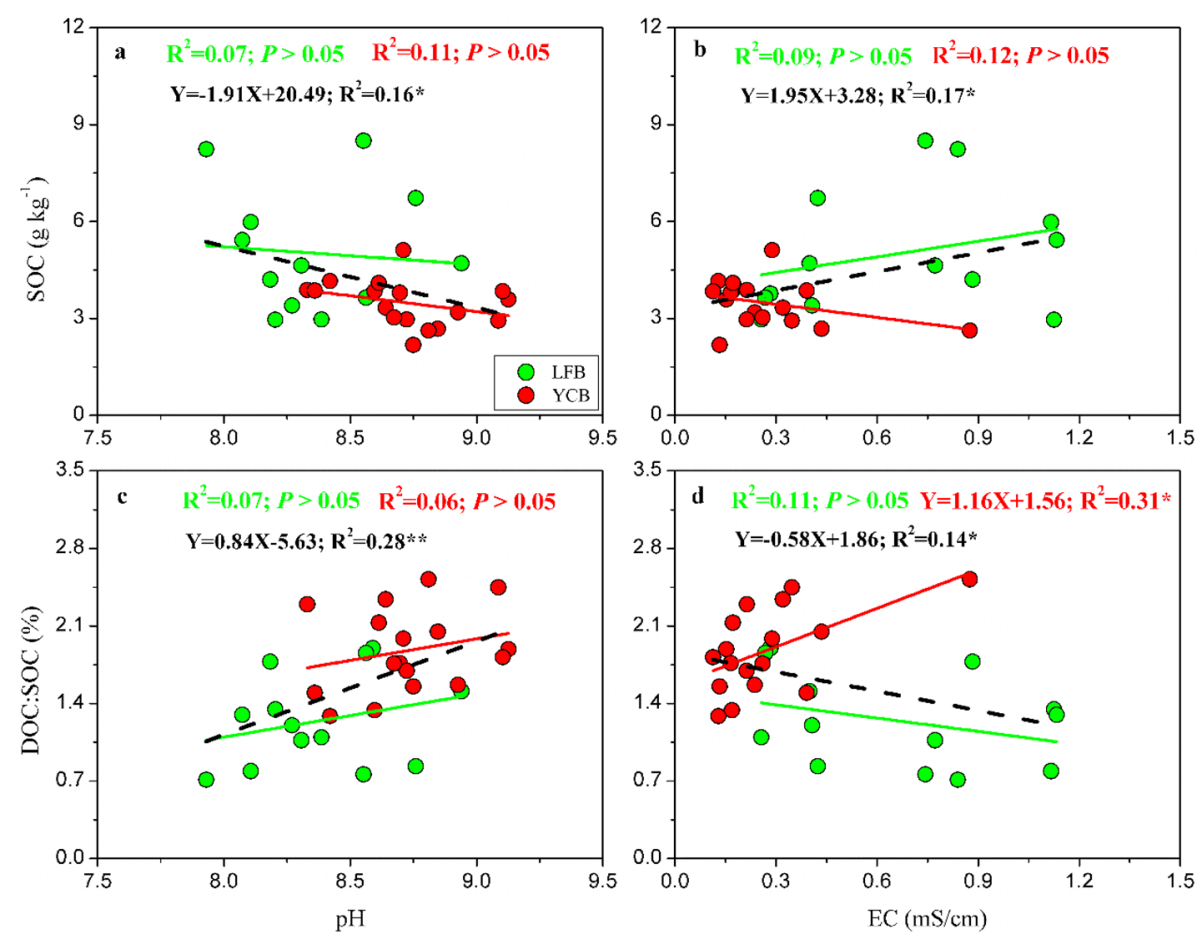

Fig. 8 Correlation between SOC (DOC:SOC) and pH or EC in the LFB, YCB and combined data (black dash lines) over $40-100 \mathrm{~cm}$. One asterisk indicates significance at $P<0.05$, and two asterisks at $P<0.01$

the formation and stabilization of soil aggregates (Rahimi et al. 2000).

Our analyses show that DOC:SOC ratio is higher in YCB $(0.76-1.88 \%)$ than in LFB $(0.61-1.24 \%)$, with a significant difference below $40 \mathrm{~cm}$ (Table 2), which indicates stronger desorption of SOC in the subsoils of YCB. Similarly, Zhang et al. (2020) reported greater DOC:SOC ratio close to the Yellow River over $60-100 \mathrm{~cm}$, relative to those in other parts of North China Plain. Apparently, the YCB and other regions that have a shorter distance to the Yellow River are influenced by stronger hydrological processes (such as water movements), which would result in more desorption and remove of DOC thus lower levels of SOC in subsoils (Zhang et al. 2020).

\section{Conclusions}

We evaluate the spatial variation, relationship and driving factors of soil carbon fractions over $0-100 \mathrm{~cm}$ in low-elevation cropland of the Loess Plateau, i.e., LFB and YCB. Our data show that SIC stock is significantly higher than SOC stock over $0-100 \mathrm{~cm}$ in the whole study area; SOC stock is negatively correlated with soil $\mathrm{pH}$, but positively correlated with EC. SOC and SIC stocks reveal a significantly negative correlation in LFB, which is partly related to erosion and re-deposition/ redistribution of topsoil. We find no clear relationship between SOC and SIC stocks in YCB, which may reflect the large spatial variations of elevation and precipitation.

Our data show a significantly positive correlation between DOC and SOC in both topsoil and subsoil of YCB, but only in the topsoil of LFB. We find that DOC:SOC ratio is significantly higher below $40 \mathrm{~cm}$ in YCB than LFB, and DOC:SOC ratio is positively correlated with soil $\mathrm{pH}$, and negatively correlated with EC. Our analyses suggest that high soil $\mathrm{pH}$ and stronger hydrological processes are attributable to the relatively lower levels of SOC in YCB. Further studies are needed to investigate how soil properties and environmental conditions interplay to regulate the dynamics of SOC and SIC in the Loess Plateau.

\section{Acknowledgements}

We want to thank Dr. Minggang Xu from the Chinese Academy of Agricultural Sciences for providing analytical facility and support.

\section{Authors' contributions}

XW provided supervision and financial support for this study, and checked/ corrected all the versions of the manuscript. TL collected soils, conducted laboratory measurements and data analyses, and prepared for the manuscript. WZ helped with sampling and analyses, and commented on earlier versions of the manuscript. All authors read and approved the final manuscript.

\section{Authors' information}

XW is a professor and chief scientist at the College of Global Change and Earth System Science, Beijing Normal University. She earned a Ph. D. in soil 
biochemistry from the Melbourne University (Australia) in 1994, and had nearly 20 years of research experience in soil carbon cycle.

\section{Funding}

National Natural Science Foundation of China (41877028).

\section{Availability of data and materials}

The research data of this study can be obtained upon by requesting the corresponding author.

\section{Competing interests}

The authors declare that they have no conflict of interests.

Received: 6 August 2020 Accepted: 17 October 2020

Published online: 02 November 2020

\section{References}

Amundson R (2001) The carbon budget in soils. Annu Rev Earth Planet Sci 29:535-562

Chang R, Fu B, Liu G, Wang S, Yao X (2012) The effects of afforestation on soil organic and inorganic carbon: A case study of the Loess Plateau of China. CATENA 95:145-152

Chen D, Yuan L, Liu Y, Ji J, Hou H (2017) Long-term application of manures plus chemical fertilizers sustained high rice yield and improved soil chemical and bacterial properties. Eur J Agron 90:34-42

Demoling F, Figueroa D, Bååth E (2007) Comparison of factors limiting bacterial growth in different soils. Soil Biol Biochem 39:2485-2495

Fu B, Liu Y, Lü Y, He C, Zeng Y, Wu B (2011) Assessing the soil erosion control service of ecosystems change in the Loess Plateau of China. Eco Complex 8:284-293

Gao Y, Dang P, Zhao Q, Liu J, Liu J (2018) Effects of vegetation rehabilitation on soil organic and inorganic carbon stocks in the Mu Us Desert, northwest China. Land Degrad Dev 29:1031-1040

Guo Y, Wang X, Li X, Wang J, Xu M, Li D (2016) Dynamics of soil organic and inorganic carbon in the cropland of upper Yellow River Delta, China. Scientific Reports 6:36105. https://doi.org/10.1038/srep36105

Han X, Gao G, Chang R, Li Z, Ma Y, Wang S, Wang C, Lü Y, Fu B (2018) Changes in soil organic and inorganic carbon stocks in deep profiles following cropland abandonment along a precipitation gradient across the Loess Plateau of China. Agr Ecosyst Environ 258:1-13

Huang C, Cong Y, Chen Y, Yang Z, Hou Q, Zhou J, Wang J, Li D, Wang H, Zhang M, Li W (2007) Fluor ine content in soils of the Linfen- Yuncheng basin, southern Shanxi, China, and its influence factors. Geo Bull China 26:878-885

Jobbágy EG, Jackson RB (2000) The vertical distribution of soil organic carbon and its relation to climate and vegetation. Ecol Appl 10:423-436

Kalbitz K, Solinger S, Park J-H, Michalzik B, Matzner E (2000) Controls on the dynamics of dissolved organic matter in soils: a review. Soil Sci 165:277-304

Kemmitt SJ, Wright D, Goulding KW, Jones DL (2006) pH regulation of carbon and nitrogen dynamics in two agricultural soils. Soil Biol Biochem 38:898-911

Lal R (2004) Soil carbon sequestration impacts on global climate change and food security. Science 304:1623

Li GT, Zhang CL, Zhang HJ, Gilkes RJ, Prakongkep N (2010): Soil inorganic carbon pool changed in long-term fertilization experiments in north China plain, World Congress of Soil Science: soil solutions for a changing world, Brisbane, 1-6 August 2010. Congress Symposium 4: Greenhouse Gases From Soils, pp. 220-223

Li M, Han X, Du S, Li L-J (2019) Profile stock of soil organic carbon and distribution in croplands of Northeast China. CATENA 174:285-292

Li Z, Nie X, He J, Chang X, Liu C, Liu L, Sun L (2017) Zonal characteristics of sediment-bound organic carbon loss during water erosion: a case study of four typical loess soils in Shaanxi Province. CATENA 156:393-400

Li ZP, Han FX, Su Y, Zhang TL, Sun B, Monts DL, Plodinec MJ (2007) Assessment of soil organic and carbonate carbon storage in China. Geoderma 138:119-126

Liu C, Li Z, Chang X, He J, Nie X, Liu L, Xiao H, Wang D, Peng H, Zeng G (2018) Soil carbon and nitrogen sources and redistribution as affected by erosion and deposition processes: a case study in a loess hilly-gully catchment, China. Agr Ecosyst Environ 253:11-22

Liu Z, Ma S, Wang Y (2011) Effect of environmental factors on regional soil organic carbon stocks across the Loess Plateau region, China. Agr Ecosyst Environ 142:184-194

Lu T, Wang X, Xu M, Yu Z, Luo Y, Smith P (2020) Dynamics of pedogenic carbonate in the cropland of the North China Plain: Influences of intensive cropping and salinization. Agr Ecosyst Environ 292:106820

Mavi MS, Marschner P, Chittleborough DJ, Cox JW, Sanderman J (2012) Salinity and sodicity affect soil respiration and dissolved organic matter dynamics differentially in soils varying in texture. Soil Biol Biochem 45:8-13

Mehra P, Sarkar B, Bolan N, Chowdhury S, Desbiolles J (2019) Impact of carbonates on the mineralisation of surface soil organic carbon in response to shift in tillage practice. Geoderma 339:94-105

Monger HC, Kraimer RA, Se K, Cole DR, Wang X, Wang J (2015) Sequestration of inorganic carbon in soil and groundwater. Geology 43:375-378

Oste LA, Temminghoff EJ, Riemsdijk WV (2002) Solid-solution partitioning of organic matter in soils as influenced by an increase in pH or Ca concentration. Environ Sci Technol 36:208-214

Raheb A, Heidari A, Mahmoodi S (2017) Organic and inorganic carbon storage in soils along an arid to dry sub-humid climosequence in northwest of Iran. CATENA 153:66-74

Rahimi H, Pazira E, Tajik F (2000) Effect of soil organic matter, electrical conductivity and sodium adsorption ratio on tensile strength of aggregates. Soil Tillage Res 54:145-153

Rowley MC, Grand S, Verrecchia ÉP (2018) Calcium-mediated stabilisation of soil organic carbon. Biogeochemistry 137:27-49

Schiettecatte W, Gabriels D, Cornelis W, Hofman G (2008) Impact of deposition on the enrichment of organic carbon in eroded sediment. CATENA 72:340-347

Shi H, Wang X, Xu M, Zhang H, Luo Y (2017) Characteristics of soil C: N ratio and $813 \mathrm{C}$ in wheat-maize cropping system of the North China Plain and influences of the Yellow River. Scientific Reports 7:16854

Shi HJ, Wang XJ, Zhao YJ, Xu MG, Li DW, Guo Y (2017) Relationship between soil inorganic carbon and organic carbon in the wheat-maize cropland of the North China Plain. Plant Soil 418:423-436

Shi X, Yu D, Warner E, Sun W, Petersen G, Gong Z, Lin H (2006) Cross-reference system for translating between genetic soil classification of China and soil taxonomy. Soil Sci Soc Am J 70:78-83

Shirale AO, Meena BP, Gurav PP, Srivastava S, Biswas AK, Thakur JK, Somasundaram J, Patra AK, Rao AS (2019) Prospects and challenges in utilization of indigenous rocks and minerals as source of potassium in farming. J Plant Nutr 42:2682-2701

Tavakkoli E, Rengasamy P, Smith E, McDonald G (2015) The effect of cationanion interactions on soil pH and solubility of organic carbon. Eur J Soil Sci 66:1054-1062

Virto I, Gartzia-Bengoetxea N, Fernández-Ugalde O (2011) Role of organic matter and carbonates in soil aggregation estimated using laser diffractometry. Pedosphere 21:566-572

Walkley A, Black IA (1934) An examination of the Degtjareff method for determining soil organic matter, and a proposed modification of the chromic acid titration method. Soil Sci 37:29-38

Wang JP, Wang XJ, Zhang J, Zhao CY (2015) Soil organic and inorganic carbon and stable carbon isotopes in the Yanqi Basin of northwestern China. Eur J Soil Sci 66:95-103

Wang XJ, Wang JP, Xu MG, Zhang WJ, Fan T, Zhang J (2015) Carbon accumulation in arid croplands of northwest China: pedogenic carbonate exceeding organic carbon. Sci Rep 5:11439

Wong VNL, Greene RSB, Dalal RC, Murphy BW (2010) Soil carbon dynamics in saline and sodic soils: a review. Soil Use Manag 26:2-11

Wu H, Guo Z, Gao Q, Peng C (2009) Distribution of soil inorganic carbon storage and its changes due to agricultural land use activity in China. Agr Ecosyst Environ 129:413-421

Zamanian K, Pustovoytov K, Kuzyakov Y (2016) Pedogenic carbonates: forms and formation processes. Earth Sci Rev 157:1-17

Zhang F, Wang X, Guo T, Zhang P, Wang J (2015) Soil organic and inorganic carbon in the loess profiles of Lanzhou area: implications of deep soils. CATENA 126:68-74

Zhang W, Wang X, Lu T, Shi H, Zhao Y (2020) Influences of soil properties and hydrological processes on soil carbon dynamics in the cropland of North China Plain. Agric Ecosyst Environ 295:106886 
Zhao W, Zhang R, Huang C, Wang B, Cao H, Koopal LK, Tan W (2016) Effect of different vegetation cover on the vertical distribution of soil organic and inorganic carbon in the Zhifanggou Watershed on the loess plateau. CATENA 139:191-198

Zheng F, He X, Gao X, Zhang C-e, Tang K (2005) Effects of erosion patterns on nutrient loss following deforestation on the Loess Plateau of China. Agr Ecosyst Environ 108:85-97

Zhong B, Xu YJ (2009) Topographic effects on soil organic carbon in Louisiana watersheds. Environ Manage 43:662-672
Zhu H, Wu J, Guo S, Huang D, Zhu Q, Ge T, Lei T (2014) Land use and topographic position control soil organic $\mathrm{C}$ and $\mathrm{N}$ accumulation in eroded hilly watershed of the Loess Plateau. CATENA 120:64-72

\section{Publisher's Note}

Springer Nature remains neutral with regard to jurisdictional claims in published maps and institutional affiliations.
Submit your manuscript to a SpringerOpen ${ }^{\odot}$ journal and benefit from:

- Convenient online submission

- Rigorous peer review

- Open access: articles freely available online

- High visibility within the field

- Retaining the copyright to your article

Submit your next manuscript at $\boldsymbol{\nabla}$ springeropen.com 